\title{
Switching of GnRH Agent from Agonist to Antagonist in Patients with Castration-Resistant Prostate Cancer
}

\author{
Shinji Fukui*, Yasushi Nakai, Yoriaki Kagebayashi, Shoji Samma \\ Department of Urology, Nara Prefecture General Medical Center, Nara, Japan \\ Email: ^doubletruth0922@yahoo.co.jp
}

How to cite this paper: Fukui, S., Nakai, Y., Kagebayashi, Y. and Samma, S. (2016) Switching of GnRH Agent from Agonist to Antagonist in Patients with CastrationResistant Prostate Cancer. Open Journal of Urology, 6, 190-198.

http://dx.doi.org/10.4236/oju.2016.612030

Received: October 15, 2016

Accepted: December 18, 2016

Published: December 21, 2016

Copyright (c) 2016 by authors and Scientific Research Publishing Inc. This work is licensed under the Creative Commons Attribution International License (CC BY 4.0).

http://creativecommons.org/licenses/by/4.0/ (c) (i) Open Access

\section{Abstract}

Objectives: To evaluate the efficacy of alteration from gonadotropin-releasing hormone $(\mathrm{GnRH})$ agonist to antagonist in patients with castration-resistant prostate cancer (CRPC). Methods: Fourteen patients with CRPC were switched from GnRH agonist to GnRH antagonist. CRPC was defined as 3 consecutive rises of PSA values under androgen deprivation therapy despite a testosterone level at the castration level. No patient underwent a change in oral anti-androgen agent or any additional therapy. Patients who showed increase of the PSA value within $10 \%$ or showed decrease in the PSA value compared to the baseline were defined as responders. We measured serum PSA, testosterone, follicular stimulating hormone (FSH), and leutenizing hormone ( $\mathrm{LH})$ at the time of alteration and 3 months after alteration. Results: The mean age at diagnosis was $74.8 \pm 6.3$ years with a mean initial PSA level of 537.3 $\pm 999.1 \mathrm{ng} / \mathrm{mL}$. The mean age at alteration to $\mathrm{GnRH}$ antagonist was 81.4 years with a mean PSA level of $28.6 \mathrm{ng} / \mathrm{mL}$. Two out of 14 patients (14\%) were judged as responders based on PSA after alteration to GnRH antagonist, although they did not show any further reduction of the serum testosterone level (remain less than 0.03). Six patients showed further reduction of the serum FSH level after alteration; however, they showed no PSA response (from $46.4 \pm 42.6$ to $69.4 \pm 70.3$ ). Conclusions: The switch from GnRH agonist to GnRH antagonist affected $14 \%$ of the patients (2 out of 14 patients) with CRPC at 3 months based on PSA. Larger and longer-term studies are required to determine the efficacy of alteration to $\mathrm{GnRH}$ antagonist in patients with CRPC.

\section{Keywords}

CRPC, GnRH Antagonist, PSA, FSH 


\section{Introduction}

Combined androgen blockade $(\mathrm{CAB})$ with gonadotropin-releasing hormone $(\mathrm{GnRH})$ agonist and anti-androgen is one of the important treatment options for patients with locally advanced or metastatic prostate cancer [1]. Multiple options for secondary treatment have been recommended for patients with castration-resistant prostate cancer (CRPC), such as alternative non-steroidal anti-androgen therapy after the exclusion of anti-androgen withdrawal syndrome, abiraterone [2] [3], enzalutamide [4] [5], lowdose steroid, estrogen preparation, and chemotherapy with docetaxel [6] or cabazitaxel [7].

GnRH antagonist (degarelix), which became clinically available in October 2012 in Japan, quickly binds to $\mathrm{GnRH}$ receptors to block their function, subsequently leading to an immediate decrease in testosterone to the castration level without a testosterone surge [8]. It was also reported that $\mathrm{GnRH}$ antagonist could extend the duration of PSA recurrence compared with GnRH agonist [9]. Few studies, however, have been reported on the efficacy of change from $\mathrm{GnRH}$ agonist to $\mathrm{GnRH}$ antagonist in patients with CRPC [10].

In this study, we assessed the utility of change from GnRH agonist to GnRH antagonist in patients with CRPC by measuring sequential changes in the values of PSA, testosterone, follicular stimulating hormone (FSH), and leutenizing hormone (LH).

\section{Patients and Methods}

This study was approved by the institutional review board at our hospital. Among patients with prostate cancer receiving $\mathrm{CAB}$ with $\mathrm{GnRH}$ agonist and anti-androgen agent in Nara Prefecture General Medical Center between January 2013 and December 2015, we included patients with CRPC who had been received $\mathrm{CAB}$ as the first-line treatment and confirmed anti-androgen withdrawal syndrome after discontinuation of anti-androgen for 4 - 6 weeks.

CRPC was defined as 3 consecutive rises in PSA under androgen deprivation therapy despite testosterone remained at the castration level (less than $0.5 \mathrm{ng} / \mathrm{mL}$ ) [10]. In the patients, GnRH agonist was altered to GnRH antagonist. Subcutaneous injection of $\mathrm{GnRH}$ antagonist was administered as directed in the literature: $240 \mathrm{mg}$ for the first injection, followed by $80 \mathrm{mg}$ every 4 weeks. No patients underwent addition of a low-dose steroids, zoledoronic acid hydrate, or denosumab after switching from GnRH agonist to GnRH antagonist. Patients who changed from anti-androgen agent to abiraterone or enzalutamide simultaneously when switching from GnRH agonist to antagonist, or patients who underwent another additional treatment were excluded from this study. Patients who did not desire to switch GnRH agonist to antagonist were also excluded from this study.

The following data were analyzed: age, PSA, clinical stage and Gleason score at diagnosis, and duration of androgen deprivation therapy. We also measured serum PSA, testosterone, FSH, and $\mathrm{LH}$ at the time of change and 3 months after change, respectively. Patients who experienced increase the PSA value within $10 \%$ or showed decrease of 
PSA value compared to the baseline were defined as responders [10]. The clinical data are presented the mean \pm standard deviation.

\section{Results}

Fourteen patients with CRPC were finally enrolled in this study. Patient characteristics are listed in Table 1. The mean age at the diagnosis of prostate cancer was $74.8 \pm 6.3$ years, the initial PSA was $537.3 \pm 999.1 \mathrm{ng} / \mathrm{mL}$ (median: 132.5 , range: $12-3770 \mathrm{ng} / \mathrm{mL}$ ), and the ALP was $370.6 \pm 369.1 \mathrm{IU} / \mathrm{L}$ (median: 273.5, range: $152-1512 \mathrm{IU} / \mathrm{L}$ ). Gleason score was 6 in two, 7 in three, 8 in four, and 9 in two. Three patients had started CAB without prostate biopsy because of high PSA levels $(382,580$, and $3770 \mathrm{ng} / \mathrm{mL}$, respectively) and poor physical conditions. Four patients were organ-confined prostate cancer, three were locally-advanced prostate cancer, and remaining seven were metastatic prostate cancer; two with distant lymph node metastasis and five with multiple bone metastasis at the diagnosis. External radiation therapy as the initial treatment had been conducted for 1 patient. The remaining 13 patients had been treated with $\mathrm{CAB}$ as the initial treatment. Nine patients were administered leuprorelin acetate and remaining five were administered goserelin acetate as $\mathrm{GnRH}$ agonist.

Table 1. Characteristics of the patients with CRPC.

\begin{tabular}{|c|c|}
\hline Age at diagnosis $( \pm \mathrm{SD})$ (years) & $74.8 \pm 6.3$ \\
\hline Initial PSA (ng/mL) & $537.3 \pm 999($ median: 132, range: $2-3770)$ \\
\hline \multicolumn{2}{|l|}{ Gleason score (case) } \\
\hline 6 & 2 \\
\hline 7 & 3 \\
\hline $8-10$ & 6 \\
\hline not done & 3 \\
\hline \multicolumn{2}{|l|}{ Clinical stage at diagnosis (case) } \\
\hline B & 3 \\
\hline $\mathrm{C}$ & 3 \\
\hline $\mathrm{D}$ & 8 \\
\hline Age at alteration $( \pm \mathrm{SD})$ (years) & $81.4 \pm 4.3$ \\
\hline Duration of agonist (months) & $79.6 \pm 63.9$ \\
\hline PSA before alterarion $(\mathrm{ng} / \mathrm{mL})$ & $28.6 \pm 35.0$ \\
\hline PSAV before alteration (ng/mL/year) & $43.3 \pm 66.4$ \\
\hline LH before alteration $(\mathrm{mIU} / \mathrm{mL})$ & $<0.1$ \\
\hline FSH before alteration $(\mathrm{mIU} / \mathrm{mL})$ & $3.4 \pm 2.7$ \\
\hline Testosterone before alteration $(\mathrm{ng} / \mathrm{mL})$ & $<0.03$ \\
\hline PSAV: PSA velocity & Mean \pm SD \\
\hline
\end{tabular}


The mean age at change to GnRH antagonist was $81.4 \pm 4.3$ years, with a mean PSA value of $28.6 \pm 35.0 \mathrm{ng} / \mathrm{mL}$ at that time. The mean hormonal treatment courses before change to $\mathrm{GnRH}$ antagonist were $2.7 \pm 1.3$ courses and the mean durations of hormonal treatment were $79.6 \pm 63.9$ months. PSA velocity immediately before change to $\mathrm{GnRH}$ antagonist was $43.3 \pm 66.4 \mathrm{ng} / \mathrm{mL} /$ year. In all 14 patients, testosterone values showed the castration level (less than $0.5 \mathrm{ng} / \mathrm{mL}$ ) at change. Fourteen percent of patients (2 out of14 patients) were judged as responders to GnRH antagonist based on PSA. PSA changes in One of the two responders showed the decrease of PSA value (from 4.97 to $3.73 \mathrm{ng} / \mathrm{mL} ;-25.0 \%$ ), and the other showed the increase of the PSA value within $10 \%$ (from 3.06 to $3.30 \mathrm{ng} / \mathrm{mL} ; 7.8 \%$ ). The PSA values in the responders were less than $5 \mathrm{ng} / \mathrm{mL}$ at the time of change to $\mathrm{GnRH}$ antagonist (4.97 and $3.06 \mathrm{ng} / \mathrm{mL}$, respectively). In all patients, testosterone was maintained at the castrate level (less than $0.5 \mathrm{ng} / \mathrm{mL}$ ) before and after change. Responders based on PSA did not show any further reduction of testosterone. Six patients showed a further reduction in the serum FSH level, although they did not respond based on PSA. The LH levels were suppressed to below the standard level after change to GnRH antagonist.

Adverse events associated with change to $\mathrm{GnRH}$ antagonist were observed in 8 patients (57\%). Injection-site reactions were the most frequent adverse events (43\%). Painful induration and erythema at the injection site were observed in 4 patients (29\%) and 2 patients (14\%), respectively, although they disappeared without any treatment within several days after injection. One patient showed high-grade fever after GnRH antagonist injection, which improved without any treatment in a few days.

One of the 2 responders based on PSA has been treated with GnRH antagonist for 20 months without PSA recurrence. The other responder based on PSA discontinued GnRH antagonist administration because of PSA recurrence 6 months after change, and returned to $\mathrm{GnRH}$ agonist with an alternative non-steroidal anti-androgen based on the patient's wishes. Five of the 12 non-responders based on PSA continued GnRH antagonist according to their request with an alternative non-steroidal anti-androgen. Six of the 12 non-responders based on PSA returned to GnRH agonist with an alternative non-steroidal anti-androgen after the 3-month evaluation of altered GnRH antagonist. The remaining one patient received chemotherapy with docetaxel. The mean follow-up period was $15.6 \pm 11.0$ months after switching to $\mathrm{GnRH}$ antagonist. Within a follow-up period, no one was died with prostate cancer. One patient was died with another cause.

A comparison of patient characteristics between the responders and non-responders based on PSA is presented in Table 2. PSA and the PSA velocity immediately before change were lower in the responder group, although statistical analysis could not be done because of a small number of the responders.

\section{Discussion}

$\mathrm{CAB}$ with a combination of injection of $\mathrm{GnRH}$ agonist and an oral anti-androgen is the most utilized modality for advanced or metastatic prostate cancer. However, the efficacy 
Table 2. Comparison of characteristics between responders and non-responders.

\begin{tabular}{|c|c|c|}
\hline & $\begin{array}{l}\text { Responders } \\
\quad(\mathrm{n}=2)\end{array}$ & $\begin{array}{c}\text { Non-responders } \\
\quad(\mathrm{n}=12)\end{array}$ \\
\hline Age at antagonist (years) & $81.5 \pm 7.8$ & $81.4 \pm 4.0$ \\
\hline Duration of agonist (months) & $80.0 \pm 61.0$ & $79.6 \pm 67.1$ \\
\hline Mean number of anti-androgen before antagonist & 3.5 & 2.6 \\
\hline PSA velocity (ng/mL/year) & $3.4 \pm 2.7$ & $49.9 \pm 69.8$ \\
\hline \multicolumn{3}{|l|}{ PSA (ng/mL) } \\
\hline before & $4.0 \pm 1.4$ & $32.7 \pm 36.3$ \\
\hline after & $3.5 \pm 69.8$ & $64.6 \pm 62.4$ \\
\hline$\%$ change from baseline & $-8.5 \%$ & $123.30 \%$ \\
\hline \multicolumn{3}{|l|}{ Testosterone (ng/mL) } \\
\hline before & $<0.03$ & $0.035 \pm 0.01$ \\
\hline after & $<0.03$ & $0.035 \pm 0.01$ \\
\hline \multicolumn{3}{|l|}{ FSH $(\mathrm{mIU} / \mathrm{mL})$} \\
\hline before & $0.48 \pm 0.6$ & $3.8 \pm 2.6$ \\
\hline after & $0.56 \pm 0.7$ & $2.7 \pm 1.9$ \\
\hline \multicolumn{3}{|l|}{$\mathrm{LH}(\mathrm{mIU} / \mathrm{mL})$} \\
\hline before & $<0.1$ & $<0.1$ \\
\hline after & $<0.1$ & $<0.1$ \\
\hline
\end{tabular}

of $\mathrm{CAB}$ is not indefinite, as the castration-resistant status would often appear within 18 24 months in patients with advanced prostate cancer [10]. Some secondary treatment options may be proposed for patients with CRPC, such as alternative non-steroidal antiandrogen therapy after the exclusion of anti-androgen withdrawal syndrome, abiraterone [2] [3], enzalutamide [4] [5], low-dose steroid, and estramustine phosphate, and chemotherapy with docetaxel [6] and cabazitaxel [7].

In assessing changes of hormone levels after administering $\mathrm{GnRH}$ agonist in patients with prostate cancer, the serum LH level showed an approximately $99 \%$ reduction compared with the baseline level, which was maintained for at least 1 year on treatment with GnRH agonist [11]. On the other hand, the serum FSH level decreased to about $75 \%$ at 1 month, and showed only an approximately 55\% reduction compared with the baseline level after one-year treatment with GnRH agonist [11]. GnRH antagonist (degarelix) facilitates a prompt decrease in testosterone to the castration level without testosterone surge [1]. It was also reported that GnRH antagonist could extend the duration of PSA recurrence compared with GnRH agonist [9]. However, there have been few reports demonstrating the efficacy of switching of GnRH agent from agonist to antagonist in patients with CRPC. GnRH antagonist rapidly achieves an approximately 
90\% reduction of FSH from the baseline level within 1 month, and maintains suppression for 1 year [11] [12]. Furthermore, GnRH antagonist showed further suppression of FSH in patients who switched from GnRH agonist to GnRH antagonist as well as that observed during continuous GnRH antagonist treatment [12].

According to immunohistochemical and immunoblotting examinations, FSH receptors were selectively expressed on the surface of blood vessels of the prostate [13]. Furthermore, FSH may affect the pathogenesis and progression of prostate cancer [14].

We hypothesized that GnRH antagonist is effective for patients with CRPC through a further reduction of FSH. In our study, GnRH agonist was switched to GnRH antagonist in patients with CRPC, and 14\% of patients (2 out of 14 patients) with CRPC were judged as responders based on PSA. Miller et al. [15] reported that 4 out of 25 patients (16\%) responded to GnRH antagonist as second-line hormonal therapy, who had been initially treated with leuprorelin acetate, and experienced PSA progression. Alexandra et al. [10] also reported that 4 out of 27 patients (23\%) responded based on PSA at 3 months after switching from $\mathrm{GnRH}$ agonist to $\mathrm{GnRH}$ antagonist. Thus, change to $\mathrm{GnRH}$ antagonist might be effective in some cases.

Alexandra et al. [10] hypothesized that change of GnRH agonist to antagonist could be efficient through further reduction of testosterone and FSH. In fact, PSA responders in their study showed the further reduction of testosterone. In our study, however, 2 non-responders based on PSA showed further reduction of testosterone. Since all of our patients had already reached the castration level before change to GnRH antagonist, this was probably the reason why GnRH antagonist barely reduced the testosterone level any further. It was recommended that serum testosterone should be maintained at less than $0.2 \mathrm{ng} / \mathrm{mL}$ in advanced prostate cancer patients receiving androgen deprivation therapy [16] [17]. Serum testosterone levels in our study were reduced to less than $0.2 \mathrm{ng} / \mathrm{mL}$ in all patients before and after change to $\mathrm{GnRH}$ antagonist.

Further reduction of FSH was observed in 6 patients after swiching to GnRH antagonist, although they were non-responders based on PSA. Further studies are necessary to investigate the relationship between the serum FSH level and the cancer progression in patients with CRPC.

de la Rosette et al. [11] demonstrated the progression of prostate cancer after switching from $\mathrm{GnRH}$ agonist to $\mathrm{GnRH}$ antagonist. Five out of 134 patients (3.7\%) showed the progression of prostate cancer: $4(2.9 \%)$ had metastatic prostate cancer, and the remaining patient had locally advanced prostate cancer. All 5 patients had high baseline PSA levels (619 - 10,952 ng/mL). This suggests that it might not be able to provide additional benefits for those with advanced prostate cancer.

Recently, Fitzpatrick et al. [18] described that it is important to evaluate the therapeutic efficacy not only PSA value but imaging studies within 3-months after initiation of treatment in patients with CRPC. In this study, however, we did not evaluate the therapeutic efficacy with imaging studies in all of the patients, and we defined patients as responders only who experienced a change in the PSA value within $10 \%$ or showed decrease of PSA compared to the baseline. 
In our study, there was no difference between responders and non-responders except for PSA and the PSA velocity immediately before change, although statistical analysis could not be done because of a small number of responders. PSA and the PSA velocity were lower in the responder group than in the non-responder group ( $4.0 \pm 1.4$ vs. 32.7 $\pm 36.3 \mathrm{ng} / \mathrm{mL}$ and $3.4 \pm 2.7$ vs. $49.9 \pm 69.8 \mathrm{ng} / \mathrm{mL} /$ year, respectively) (Table 2). High PSA values and high PSA velocities indicate advanced prostate cancer, and our results suggest that these 2 parameters could be prognostic factors to predict the efficacy of change to GnRH antagonist in patients with CRPC.

Treatment options are limited in patients with CRPC. Although the effects were limited only based on PSA in our study, it appears that switching from GnRH agonist to $\mathrm{GnRH}$ antagonist could be one of the treatment options because it might facilitate the control of prostate cancer progression in some cases, and could delay the induction of chemotherapy with docetaxel and cabazitaxel.

The limitations of this study are the very small number of patients and relatively short duration of follow-up. Additional number of patients with CRPC are needed to evaluate sequential changes in the values of PSA, testosterone, FSH and LH after switching from GnRH agonist to antagonist. Because there have been few studies reporting the effects of switching from GnRH agonist to GnRH antagonist on patients with CRPC, further prospective studies are required to evaluate the efficacy of change to $\mathrm{GnRH}$ antagonist, and to verify if PSA and the PSA velocity immediately before change could be used to predict the efficacy of change. In addition, further studies are necessary to determine whether change to GnRH antagonist could be a second-line hormone therapy for patients with CRPC.

\section{Conclusion}

The change from GnRH agonist to GnRH antagonist affected 14\% of patients (2 out of 14 patients) with CRPC at 3 months based on PSA values. Larger and longer-term studies are necessary to evaluate the efficacy of change to $\mathrm{GnRH}$ antagonist.

\section{Conflict of Interest Statement}

The authors declare that they have no conflict of interest.

\section{References}

[1] Hinotsu, S., Akaza, H., Usami, M., Ogawa, O., Kagawa, S., Kitamura, T., Tsukamoto, T., Naito, S., Namiki, M., Hirao, Y., Murai, M. and Yamanaka, H. (2007) Current Status of Endocrine Therapy for Prostate Cancer in Japan Analysis of Primary Androgen Deprivation Therapy on the Basis of Data Collected by J-CaP. Japanese Journal of Clinical Oncolo$g y, 37$, 775-781. https://doi.org/10.1093/jjco/hym098

[2] de Bono, J.S., Logothetis, C.J., Molina, A., Fizazi, K., North, S., Chu, L., Chi, K.N., Jones, R.J., Goodman, O.B. Jr., Saad, F., Staffurth, J.N., Mainwaring, P., Harland, S., Flaig, T.W., Hutson, T.E., Cheng, T., Patterson, H., Hainsworth, J.D., Ryan, C.J., Sternberg, C.N., Ellard, S.L., Fléchon, A., Saleh, M., Scholz, M., Efstathiou, E., Zivi, A., Bianchini, D., Loriot, Y., Chieffo, N., Kheoh, T., Haqq, C.M. and Scher, H.I. (2011) Abiraterone and Increased Sur- 
vival in Metastatic Prostate Cancer. The New England Journal of Medicine, 364, 1995-2005. https://doi.org/10.1056/NEJMoa1014618

[3] Ryan, C.J., Smith, M.R., de Bono, J.S., Molina, A., Logothetis, C.J., de Souza, P., Fizazi, K., Mainwaring, P., Piulats, J.M., Ng, S., Carles, J., Mulders, P.F., Basch, E., Small, E.J., Saad, F., Schrijvers, D., Van Poppel, H., Mukherjee, S.D., Suttmann, H., Gerritsen, W.R., Flaig, T.W., George, D.J., Yu, E.Y., Efstathiou, E., Pantuck, A., Winquist, E., Higano, C.S., Taplin, M.E., Park, Y., Kheoh, T., Griffin, T., Scher, H.I. and Rathkopf, D.E. (2013) Abiraterone in Metastatic Prostate Cancer without Previous Chemotherapy. The New England Journal of Medicine, 368, 138-148. https://doi.org/10.1056/NEJMoa1209096

[4] Scher, H.I., Fizazi, K., Saad, F., Taplin, M.E., Sternberg, C.N., Miller, K., de Wit, R., Mulders, P., Chi, K.N., Shore, N.D., Armstrong, A.J., Flaig, T.W., Fléchon, A., Mainwaring, P., Fleming, M., Hainsworth, J.D., Hirmand, M., Selby, B., Seely, L. and de Bono, J.S. (2012) Increased Survival with Enzalutamide in Prostate Cancer after Chemotherapy. The New England Journal of Medicine, 367, 1187-1197. https://doi.org/10.1056/NEJMoa1207506

[5] Beer, T.M., Armstrong, A.J., Rathkopf, D.E., Loriot, Y., Sternberg, C.N., Higano, C.S., Iversen, P., Bhattacharya, S., Carles, J., Chowdhury, S., Davis, I.D., de Bono, J.S., Evans, C.P., Fizazi, K., Joshua, A.M., Kim, C.S., Kimura, G., Mainwaring, P., Mansbach, H., Miller, K., Noonberg, S.B., Perabo, F., Phung, D., Saad, F., Scher, H.I., Taplin, M.E., Venner, P.M. and Tombal, B. (2014) Enzalutamide in Metastatic Prostate Cancer before Chemotherapy. The New England Journal of Medicine, 371, 424-433. https://doi.org/10.1056/NEJMoa1405095

[6] Tannock, I.F., de Wit, R., Berry, W.R., Horti, J., Pluzanska, A., Chi, K.N., Oudard, S., Théodore, C., James, N.D., Turesson, I., Rosenthal, M.A. and Eisenberger, M.A. (2004) Docetaxel plus Prednisone or Mitoxantrone plus Prednisone for Advanced Prostate Cancer. The New England Journal of Medicine, 351, 1502-1512. https://doi.org/10.1056/NEJMoa040720

[7] de Bono, J.S., Oudard, S., Ozguroglu, M., Hansen, S., Machiels, J.P., Kocak, I., Gravis, G., Bodrogi, I., Mackenzie, M.J., Shen, L., Roessner, M., Gupta, S. and Sartor, A.O. (2010) Prednisone plus Cabazitaxel or Mitoxantrone for Metastatic Castration-Resistant Prostate Cancer Progressing after Docetaxel Treatment: A Randomised Open-Label Trial. The Lancet, 376, 1147-1154. https://doi.org/10.1016/S0140-6736(10)61389-X

[8] Klotz, L., Boccon-Gibod, L., Shore, N.D., Andreou, C., Persson, B.E., Cantor, P., Jensen, J.K., Olesen, T. K. and Schröder, F.H. (2008) The Efficacy and Safety of Degarelix: A 12 Month, Comparative, Randomized, Open-Label, Parallel-Group Phase III Study in Patients with Prostate Cancer. BJU International, 102, 1531-1538.

https://doi.org/10.1111/j.1464-410X.2008.08183.x

[9] Tombal, B., Miller, K., Boccon-Gibod, L., Schröder, F., Shore, N., Crawford, E.D., Moul, J., Jensen, J.K., Kold Olesen, T. and Persson, B.E. (2010) Additional Analysis of the Secondary End Point of Biochemical Recurrence Rate in a Phase 3 Trial (CS21) Comparing Degarelix $80 \mathrm{mg}$ versus Leuprolide in Prostate Cancer Patients Segmented by Baseline Characteristics. European Urology, 57, 836-842. https://doi.org/10.1016/j.eururo.2009.11.029

[10] Alexandra, M.L., Guy, L., Pedron, P., Bruyere, F., Rouprêt, M., Nsabimbona, B., Dahan, M., Hoffman, P., Salomon, L., Vordos, D., Hoznek, A., Le Corvoisier, P., Morel, P., Abbou, C. and de la Taille, A. (2013) A Switch from GnRH Agonist to GnRH Antagonist in Castration-Resistant Prostate Cancer Patients Leads to a Low Response Rate on PSA. World Journal of Urology, 31, 339-343. https://doi.org/10.1007/s00345-012-0841-1

[11] de la Rosette, J., Davis 3rd, R., Frankel, D. and Kold Olsen, T. (2011) Efficacy and Safety of Androgen Deprivation Therapy after Switching from Monthly Leuprolide to Monthly Degarelix in Patients with Prostate Cancer. International Journal of Clinical Practice, 65, 559- 
566. https://doi.org/10.1111/j.1742-1241.2011.02637.x

[12] Crawford, E.D., Tombal, B., Miller, K., Boccon-Gibod, L., Schröder, F., Shore, N., Moul, J.W., Jensen, J.K., Olesen, T.K. and Persson, B.E. (2011) A Phase III Extension Trial with a 1-Arm Crossover from Leuprolide to Degarelix: Comparison of Gonadotropin-Releasing Hormone Agonist and Antagonist Effect on Prostate Cancer. The Journal of Urology, 186, 889-897. https://doi.org/10.1016/j.juro.2011.04.083

[13] Radu, A., Pichon, C., Camparo, P., Antoine, M., Allory, Y., Couvelard, A., Fromont, G., Hai, M.T. and Ghinea, N. (2010) Expression of Follicle-Stimulating Hormone Receptor in Tumor Blood Vessels. The New England Journal of Medicine, 363, 1621-1630. https://doi.org/10.1056/NEJMoa1001283

[14] Porter, A.T., F.A.C.R.O. and Ben-Josef, E. (2001) Humoral Mechanisms in Prostate Cancer: A Role for FSH. Urologic Oncology, 6, 131-138. https://doi.org/10.1016/S1078-1439(00)00124-1

[15] Miller, K., Russel, C., Goble, S. and Persson, B.E. (2010) Open Label, Exploratory Study of Degarelix as Second-Line Hormonal Therapy in Patients with Prostate Cancer (CS27). European Urology Supplements, 9, 76. https://doi.org/10.1016/S1569-9056(10)60144-3

[16] Morote, J., Orsola, A., Planas, J., Trilla, E., Raventós, C.X., Cecchini, L. and Catalán R. (2007) Redefining Clinically Significant Castration Levels in Patients with Prostate Cancer Receiving Continuous Androgen Deprivation Therapy. The Journal of Urology, 178, 12901295. https://doi.org/10.1016/j.juro.2007.05.129

[17] Rove, K.O., Debruyne, F.M., Djavan, B., Gomella, L.G., Koul, H.K., Lucia, M.S., Petrylak, D.P., Shore, N.D., Stone, N.N. and Crawford, E.D. (2012) Role of Testosterone in Managing Advanced Prostate Cancer. Urology, 80, 754-762.

https://doi.org/10.1016/j.urology.2012.05.006

[18] Fitzpatrick, J.M., Bellmunt, J., Fizazi, K., Heidenreich, A., Sternberg, C.N., Tombal, B., Alcaraz, A., Bahl, A., Bracarda, S., Di Lorenzo, G., Efstathiou, E., Finn, S.P., Fosså, S., Gillessen, S., Kellokumpu-Lehtinen, P.L., Lecouvet, F.E., Oudard, S., de Reijke, T.M., Robson, C.N., De Santis, M., Seruga, B. and de Wit, R. (2014) Optimal Management of Metastatic Castration-Resistant Prostate Cancer: Highlights from a European Expert Consensus Panel. European Journal of Cancer, 50, 1617-1627. https://doi.org/10.1016/j.ejca.2014.03.010 
Submit or recommend next manuscript to SCIRP and we will provide best service for you:

Accepting pre-submission inquiries through Email, Facebook, LinkedIn, Twitter, etc. A wide selection of journals (inclusive of 9 subjects, more than 200 journals)

Providing 24-hour high-quality service

User-friendly online submission system

Fair and swift peer-review system

Efficient typesetting and proofreading procedure

Display of the result of downloads and visits, as well as the number of cited articles

Maximum dissemination of your research work

Submit your manuscript at: http://papersubmission.scirp.org/

Or contact oju@scirp.org 